Periodica Polytechnica Civil Engineering, 66(2), pp. 445-459, 2022

\title{
Seismic Assessment of the Historical Sütlü Minaret Mosque
}

\author{
Muslum Murat Maras ${ }^{1}$, Alper Özmen¹, Erkut Sayın²*, Yaşar Ayaz ${ }^{1}$ \\ ${ }^{1}$ Engineering Faculty, Civil Engineering Department, Inonu University, 44280, Malatya, Turkey \\ ${ }^{2}$ Engineering Faculty, Civil Engineering Department, Firat University, 23119, Elazı $\breve{g}$, Turkey \\ * Corresponding author, e-mail: esayin@firat.edu.tr
}

Received: 13 October 2021, Accepted: 16 January 2022, Published online: 25 January 2022

\begin{abstract}
Historical masonry structures that connecting the past to the present have great importance because they represent the experiences and characteristics of various cultures. Therefore, the protection of historical structures is important. In this study, the structural response of the historical masonry Mosque was evaluated through dynamic analyses. For this purpose, the Sütlü Minaret Mosque which is located in Malatya, Turkey, was investigated. The three-dimensional model of the historical mosque was generated with ANSYS software. The material properties of the mosque were obtained with experimental tests. The time history analyses were used to obtain the seismic behavior of masonry mosque. In the time history analyses, six different strong ground motion records, including the 2020 Elazı $\breve{g}$ earthquake, were used. After the analysis, displacement and stress values in the mosque were given. The absolute peak displacement value among these earthquake records was obtained from the 1999 Düzce earthquake and the highest principal compressive and tensile stress values were determined for the 2010 Darfield earthquake. Also, the crack regions which occurred in the mosque after the 2020 Elazığ earthquake were compared with the dynamic analysis result of the 2020 Elazı ğ earthquake. The crack regions formed after the Elazığ earthquake are similar to the possible crack regions formed after the dynamic analysis.
\end{abstract}

Keywords

historical masonry mosque, time history analysis, finite element analyses, structural assessment

\section{Introduction}

In Turkey, seismicity is significantly high, and Turkey contains numerous historical structures of different civilizations, which survived from past to present. It is important to protect and transfer these historical structures to future generations. These structures, which are parts of the cultural heritage have been exposed to various external factors, such as earthquakes, etc., from past to present. Among the external factors, these structures are negatively affected by earthquakes the most, and as a result, they are either destroyed or damaged in a way that renders them unusable. To prevent the damages of earthquakes, the characteristics of these structures should be determined, and then, models that can represent the actual behaviors of the structures by various analysis methods. There are several studies in the literature about earthquake behavior of historical structures. Some of the papers published in recent years can be mentioned here. Portioli et al. [1] evaluated the seismic behavior of Mustafa Pasha Mosque in Skopje. Also, they investigated efficiency of a CFRPbased strengthening technique. Linear dynamic and nonlinear static analyses were performed to design the retrofitting intervention and to analyze the seismic behavior of the large-scale model before and after strengthening. Seker et al. [2] investigated the structural performance of a masonry mosque. For this purpose, historical Kara Mustafa Pasha Mosque was selected as a numerical example. Three-dimensional finite element model of the mosque was generated and the structural responses were investigated through static and dynamic analyzes. Koseoglu and Canbay [3] studied damaged single domed mosque of $16^{\text {th }}$ century classical Ottoman Architecture. They performed linear response spectrum analysis to assess the seismic performance of the mosque. Altunışık and Genç [4] studied the restoration effect on the earthquake behavior of historical masonry mosque considering different opening ratios on the dome. Linear dynamic analyses were performed. Maximum displacements and maximum-minimum principal stresses were obtained. Güllü and Karabekmez [5] investigated the effects of near and far-fault earthquakes on the seismic responses of a historical stone masonry mosque through soil-structure-interaction (SSI) analysis as well as fixed base solution. For this 
purpose, five strong ground motion records were selected. They found from the analysis results that the near and far-fault earthquakes mostly lead to the responses similarly significant for both the fixed base and SSI considerations. Usta and Bozdağ [6] evaluated historical Basdurak mosque via time-history dynamic analyses.

As a result of the analysis, displacements and stresses were obtained and structural safety of the mosque was evaluated. In a study conducted by Bayraktar et al. [7], the Historical Fatih Mosque was evaluated as the sample. The mosque was modeled by the three-dimensional finite element method. Structural behaviors of the mosque with and without window openings were compared considering displacement and stress propagations. Briccola and Bruggi [8] was presented a numerical approach to perform the equilibrium of three-dimensional linear elastic masonry-like structures exploiting the application programming interface of a general purpose software package that performs finite element analysis. In addition, there are various publications on historical bridges [9-10], historical churches [11-12], historical mosque, minarets and towers [13-15].

In this study, historical masonry Sütlü Minaret Mosque which is located in Malatya, Turkey, was evaluated. The single-domed mosque, built during the Ottoman period, dates back to the $17^{\text {th }}$ century. According to the knowledge of the authors, the historical mosque evaluated in this study, despite being an important part of the cultural heritage of the region, has not been investigated before. For this purpose, the mosque was modelled with three dimensional finite element model with ANSYS finite element software. The material properties of the mosque were obtained with nondestructive methods and laboratory tests. Structural response of the mosque was investigated through linear dynamic analyses. In the dynamic analyses, six different strong ground motions records were used. The crack regions which occurred in the mosque after the Elazığ earthquake were compared with the dynamic analysis results.

\section{Seismicity of the region}

Turkey is located on a seismically active region. It is located in the zone of convergence between the Arabian, African and the Eurasian plates. The westward motion of the Anatolian plate is accommodated by the North and East Anatolian faults [16]. These faults connect at Karlova in the Eastern Anatolia and make the Karlıova triple junction. The East Anatolian Fault (EAF) is an NW-SE trending left-lateral strike-slip fault for a length of about $550 \mathrm{~km}$ long [17-19]. East Anatolian Fault Zone passes through Elazığ. Due to the seismic activity in its location, destructive earthquakes have occurred in Elazı $\breve{g}$ and its surroundings in the past (Fig. 1). On January 24, 2020, a strong earthquake has been effective in Sivrice district of Elazı ğ at 20:55 local time. The magnitude and focus depth of the earthquake was recorded as $M_{w}=6.8$ and $h=8.06 \mathrm{~km}$ by the Disaster

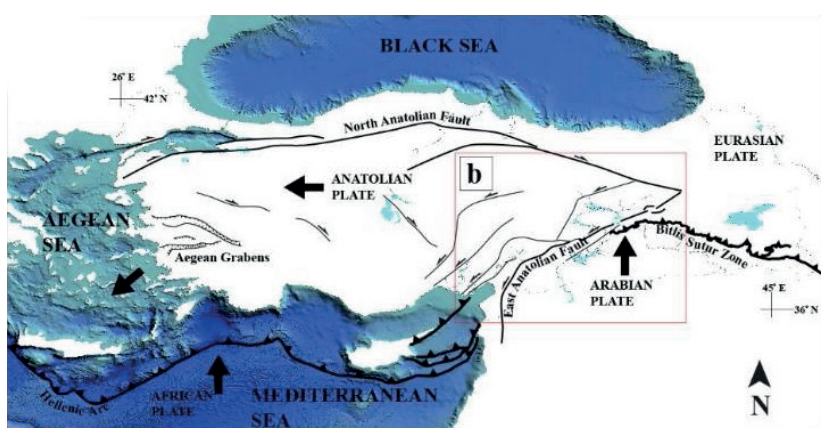

(a)

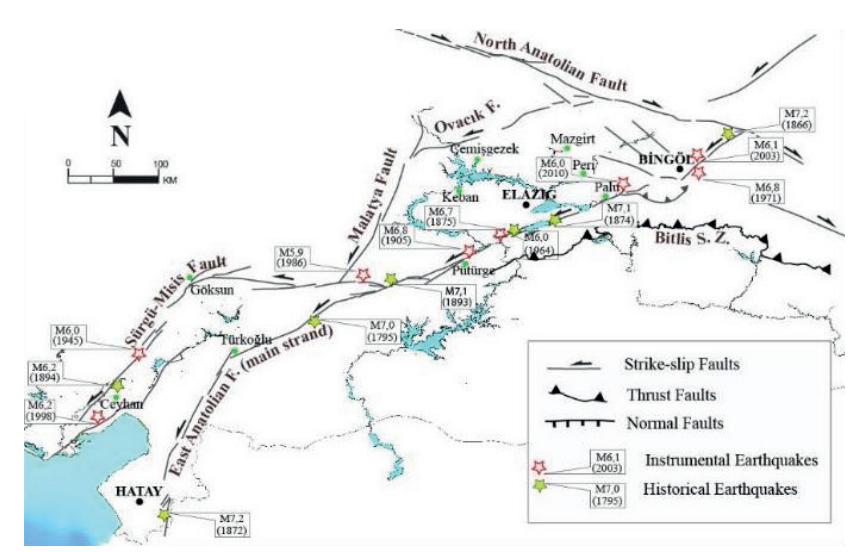

(b)

TURKEY EARTHQUAKE HAZARD MAP
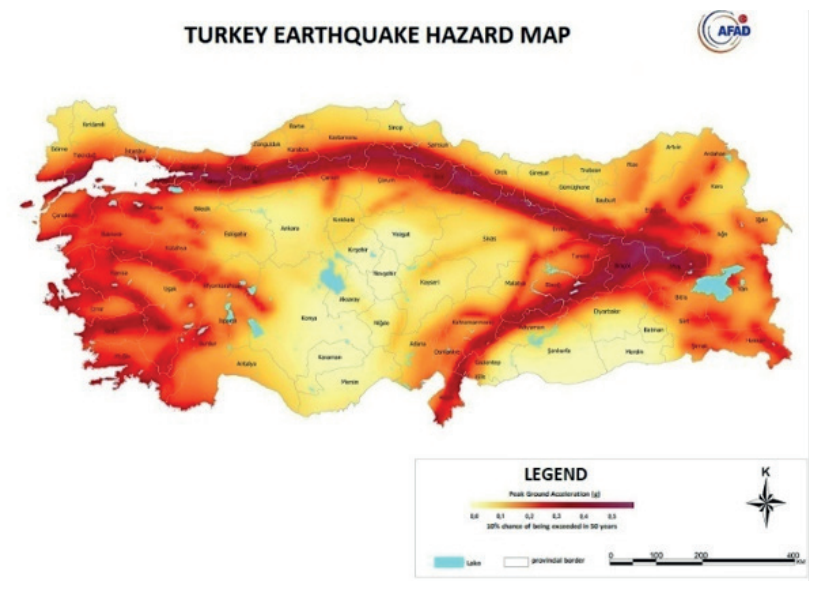

(c)

Fig. 1 a) Simplified main tectonic features of Turkey and westward motion of Anatolian plate, b) Tectonic map of Eastern Anatolia, and historical and instrumental seismicity along the EAF, c) Earthquake Hazard Map of Turkey [20, 21] 
and Emergency Management Agency, respectively [20]. The earthquake mainly affected the cities of Elazı $\breve{g}$ and Malatya. The epicenter of the earthquake is approximately $65 \mathrm{~km}$ away from the center of the city of Malatya. The main shock caused significant damage and resulted in 41 casualties. Many large earthquakes occurred on the EAF in the historical and instrumental periods. 8 March 2010 $M_{w}=6.1$ at Okçular (Elazığ), 1 May $2003 M_{w}=6.4$ at Bingöl, 27 June $1998 M_{w}=6.2$ at Adana and 5 May 1986 M 6.0 at Malatya earthquakes are damaging earthquakes occurred on the EAF in the last century. The historical earthquake catalog summarized by Soysal et al. [22], includes several major earthquakes with uncertain magnitude but with estimated maximum Mercalli intensities as follows: 995 Palu-Elazığ (VI), 1114 Ceyhan-Antakya (IX), 1268 Kozan-Ceyhan (IX), 1737 Antakya (VII), 1855 CeyhanAdana (VI), 1872 Samandağ-Antakya (IX), 1874 MadenElazığ (VIII), 1875 Sivrice-Elazı̆̆ (VIII).

\section{Historical Sütlü Minaret Mosque}

The Historical Sütlü Minaret Mosque is located outside of the city walls in the Battalgazi District of the City of Malatya and is an Ottoman structure with a single dome (Fig. 2). In terms of the materials, because the mosque was built with stones that maintained their white color and looked clean, the mosque is called "Sütlü" according to its appearance, which means "milky". Elevation views of the mosque are presented in Fig. 3. The mosque is quadruplefronted. The wall is built with coursed rubble stones approximately $180 \mathrm{~cm}$ from the ground. In the initial survey, it was observed that two different types of stones were used in the structure and the walls inside the structure were completed covered with plaster. The mosque has an elevation in the west-east direction. The west of the mosque, where the entry to the mosque is located, faces the road. The minaret of the mosque is approximately $21 \mathrm{~m}$ tall, and the body of the minaret has a diameter of $162 \mathrm{~cm}$. The body section of the minaret was built with bricks. The pulpit has a stone coating. There is no information about the construction date of the mosque. However, it is estimated that the mosque was built in the $16^{\text {th }}$ century due to its similarity to the Ak Minaret Mosque in Malatya.

It is thought that the mosque was repaired in 1808 according to the inscription on the mosque. Also, the mosque was restored by The Directorate General of Foundations in 2005.

\section{Determination of material properties}

The material characteristics of the mosque were determined by on-site analyses, which were nondestructive, and laboratory experiments that were conducted on the test samples. The permissions for the nondestructive tests and samples from the stones in restoration were obtained from the Municipality of Battalgazi in Malatya.

\subsection{Nondestructive methods}

Determination of material characteristics of historical structures can be rather complex. Non-destructive techniques are generally used in the study of historical structures because of the high cultural value of these structures. In this study, the Schmidt hammer and ultrasound test methods, were conducted to determine the material characteristics of the structure. The walls of the structure were consisted of two groups as the original stones and restoration stones. The surface hardness was evaluated
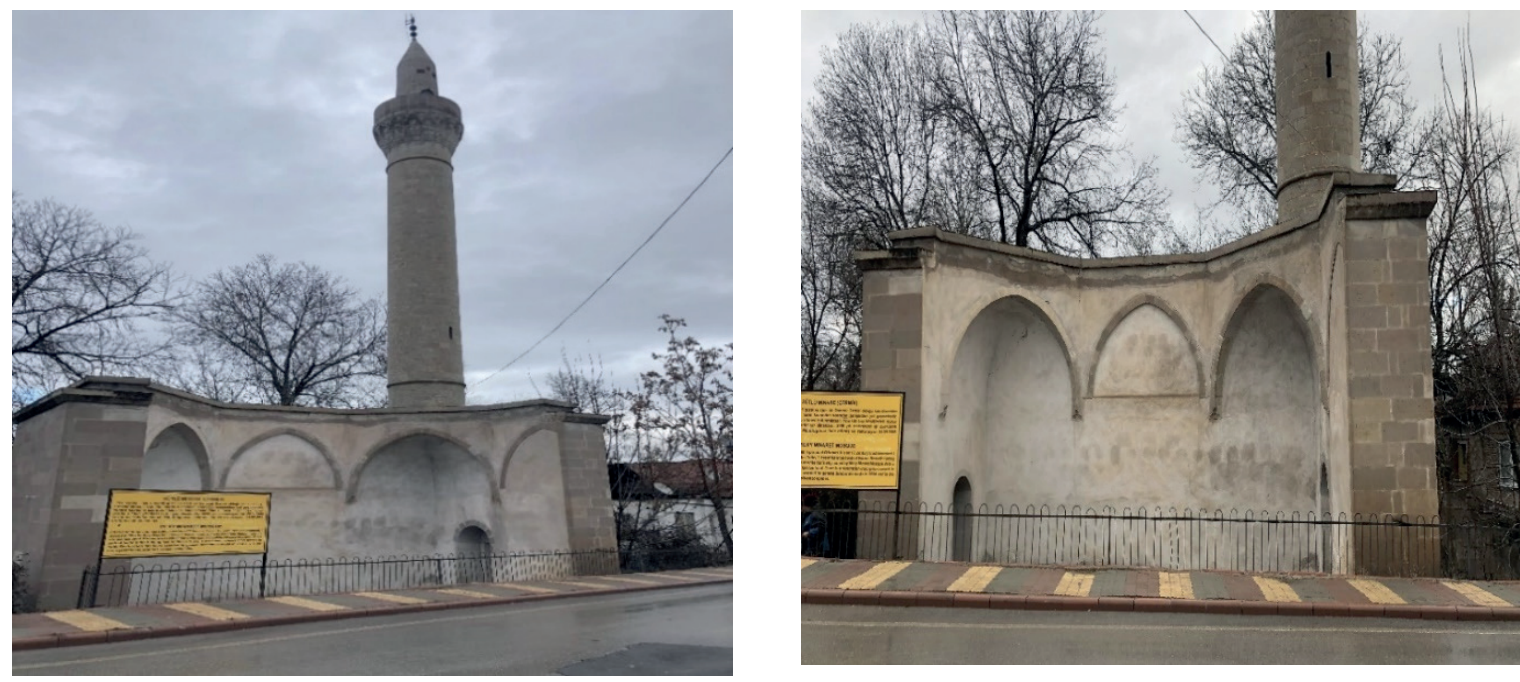

Fig. 2 General view of the historical Sütlü mosque 


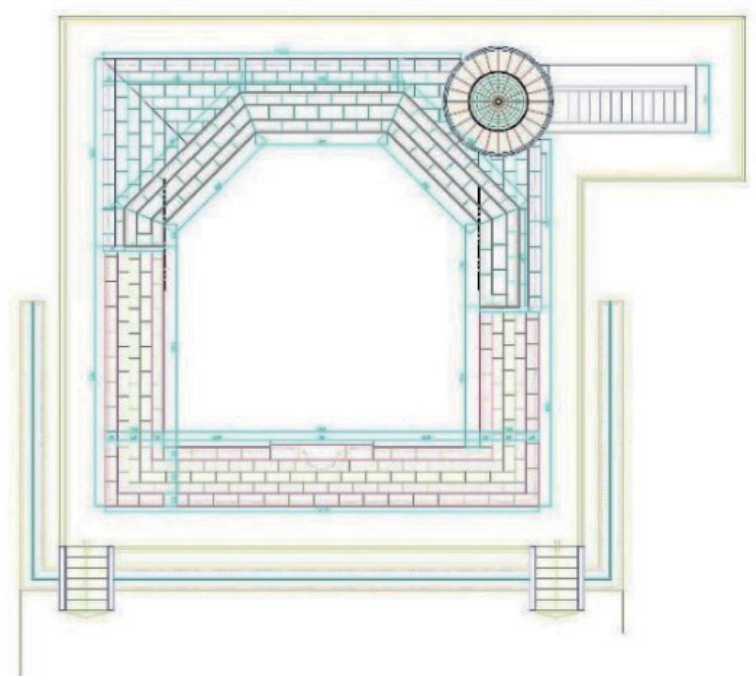

(a)

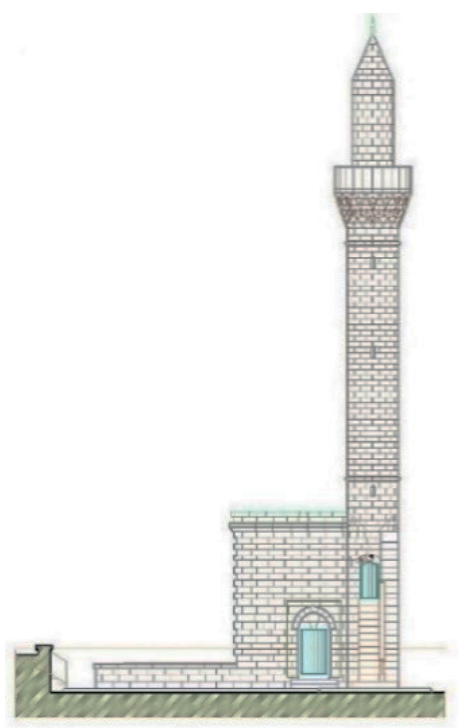

(c)

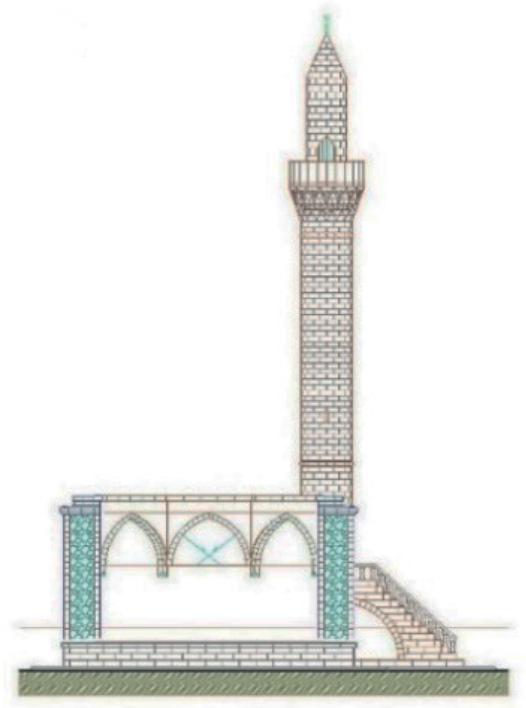

(b)

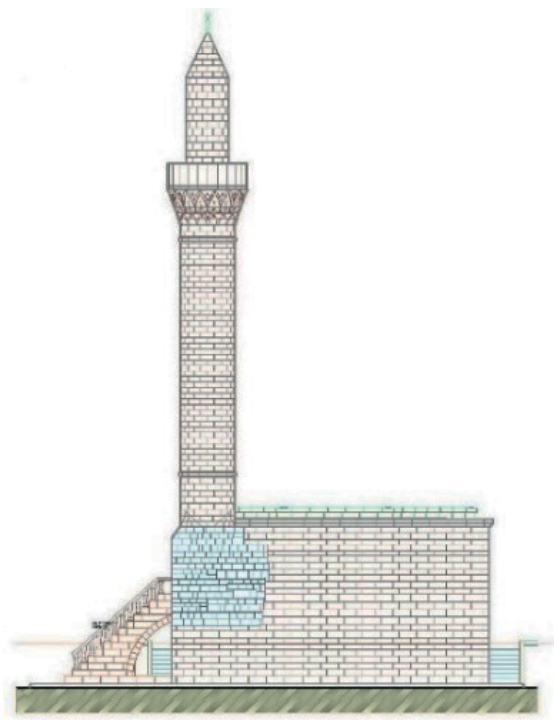

(d)

Fig. 3 Elevation views of the historical Sütlü mosque a) Plan view, b) Southern façade, c) Eastern façade, d) Northern façade

in 10 different points. The readings obtained from the restoration stones were presented in red while the readings of the original stones were presented in blue color (Fig. 4). The hardness measurement values were conducted according to ISRM 1978 [23]. According to ASTM D 5873-14 [24], a total of 20 values were read per sample, and the average value of the surface hardness was calculated. The hardness measurement values of the walls of the historical mosque were presented in Table 1 in detail.

In the determination of elasticity modulus, ultrasound tests are used frequently $[25,26]$. In this study, ultrasound methods, were used for masonry building elements, and the dynamic elasticity modulus was determined according to ISRM 1978 [27] (Table 2). The propagation velocity of compression $\left(V_{p}\right)$ and shear $\left(V_{s}\right)$ pulses was applied according to the ASTM D 2845-05 [28]. Ultrasound velocity measurement tests were conducted on different points of the structure (Fig. 5). The Poisson ratio (v) and the specific weight $(\rho)$ of the stone were determined in the laboratory test. Also, the propagation velocity of compression $\left(V_{p}\right)$ and shear $\left(V_{s}\right)$ pulses was obtained. The Elastic modulus attained from the compression (destructive) test is called the static elastic modulus $\left(E_{s t}\right)$. The dynamic elasticity modulus $\left(E_{d y n}\right)$ is calculated using the ultrasonic (non-destructive) test method [29]. This is because destructive test methods are not appropriate for historical structures. Furthermore, in cases where it is not possible determine the characteristics of the stone using destructive tests, the 

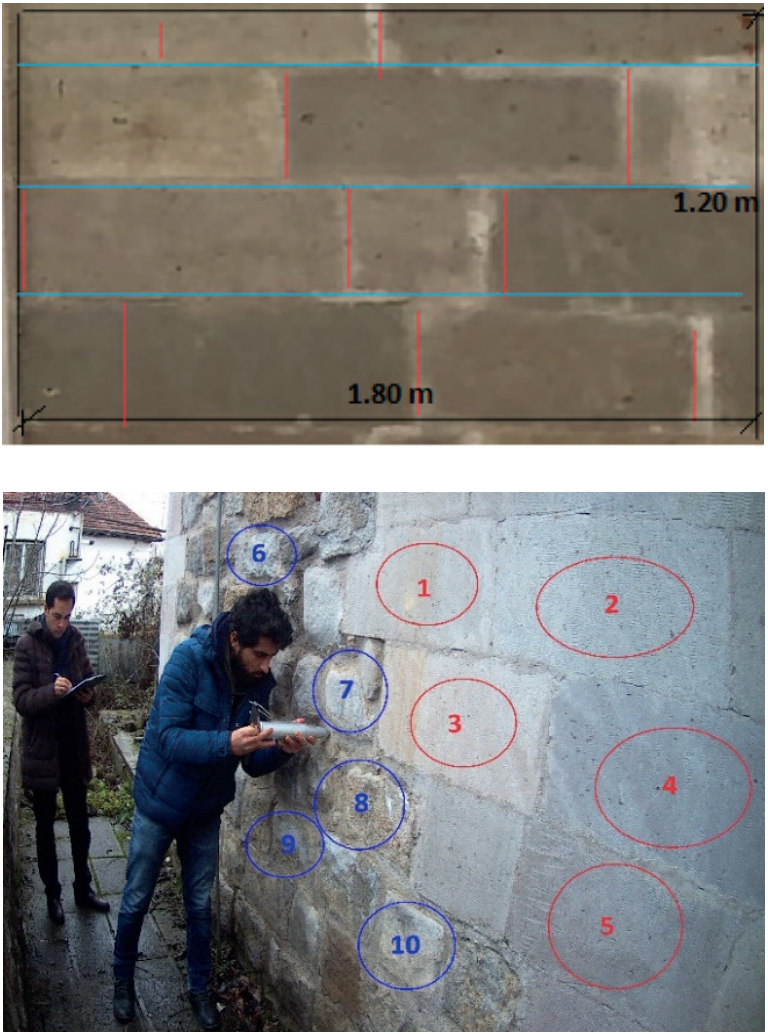

Fig. 4 Surface hardness measurement

Table 1 The surface hardness measurement of the mosque by using the Schmidt hammer

\begin{tabular}{lcccc}
\hline Location & $\begin{array}{c}\text { Rebound leeb } \\
\text { numbers }\end{array}$ & Class & Range & Indicated quality \\
\hline 1 & 31 & B & $25-34$ & Moderate \\
2 & 36 & C & $35-44$ & Normal \\
3 & 34 & C & $35-44$ & Normal \\
4 & 35 & B & $25-34$ & Moderate \\
5 & 51 & C & $35-44$ & Normal \\
6 & 45 & D & $45-54$ & Hard \\
7 & 43 & D & $45-54$ & Hard \\
8 & 45 & C & $35-44$ & Normal \\
9 & 45 & D & $45-54$ & Hard \\
10 & 41 & C & $35-44$ & Normal \\
\hline
\end{tabular}

Table 2 Determination of the dynamic elasticity modulus

\begin{tabular}{lccccc}
\hline $\begin{array}{l}\text { Measurement } \\
\text { Location }\end{array}$ & $\begin{array}{l}\rho(\mathrm{g} / \\
\left.\mathrm{cm}^{3}\right)\end{array}$ & $v$ & $\begin{array}{c}V_{p} \\
(\mathrm{~m} / \mathrm{s})\end{array}$ & $\begin{array}{c}V_{s} \\
(\mathrm{~m} / \mathrm{s})\end{array}$ & $\begin{array}{c}E_{d y n} \\
(\mathrm{GPa})\end{array}$ \\
\hline Original Stone & 2.18 & 0.20 & 3.612 & 2.669 & 25.60 \\
Restoration Stone & 1.95 & 0.23 & 2.773 & 1.642 & 12.94 \\
\hline
\end{tabular}

use of non-destructive techniques provides a convenient alternative [30]. The dynamic elasticity modulus $\left(E_{d y n}\right)$ was found using Eqs. (1) and (2). The relevant expressions are provided below [31].
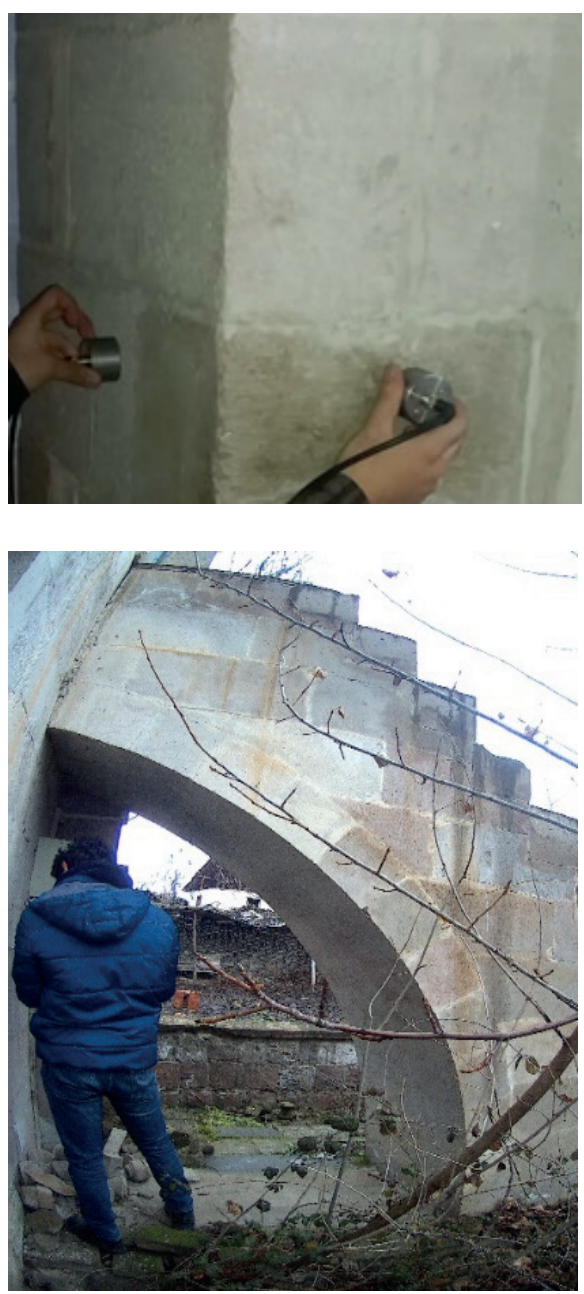

Fig. 5 Ultrasound test application

$V p=\sqrt{\frac{E_{d y n}(1-v)}{\rho(1+v)(1-2 v)}}$

$V s=\sqrt{\frac{E_{d y n}}{2 \rho(1+v)}}$

\subsection{Laboratory experiments}

To determine the mechanical characteristics of the stones used in the mosque, tensile and compression tests were conducted. For this purpose, the uniaxial compressive strength tests of the stones were conducted according to ISRM 1978 [32]. Test samples were prepared as cylinders with a height-to-diameter ratio of 2.0-2.5 for the uniaxial compression test according to ISRM. Samples were prepared as $54 \mathrm{~mm}$ diameters and 2-2.5 length/diameter ratios (Fig. 6). The compressive strength value of the specimen was calculated by using Eq. (3).

$\sigma=\frac{P_{k}}{A}$ 

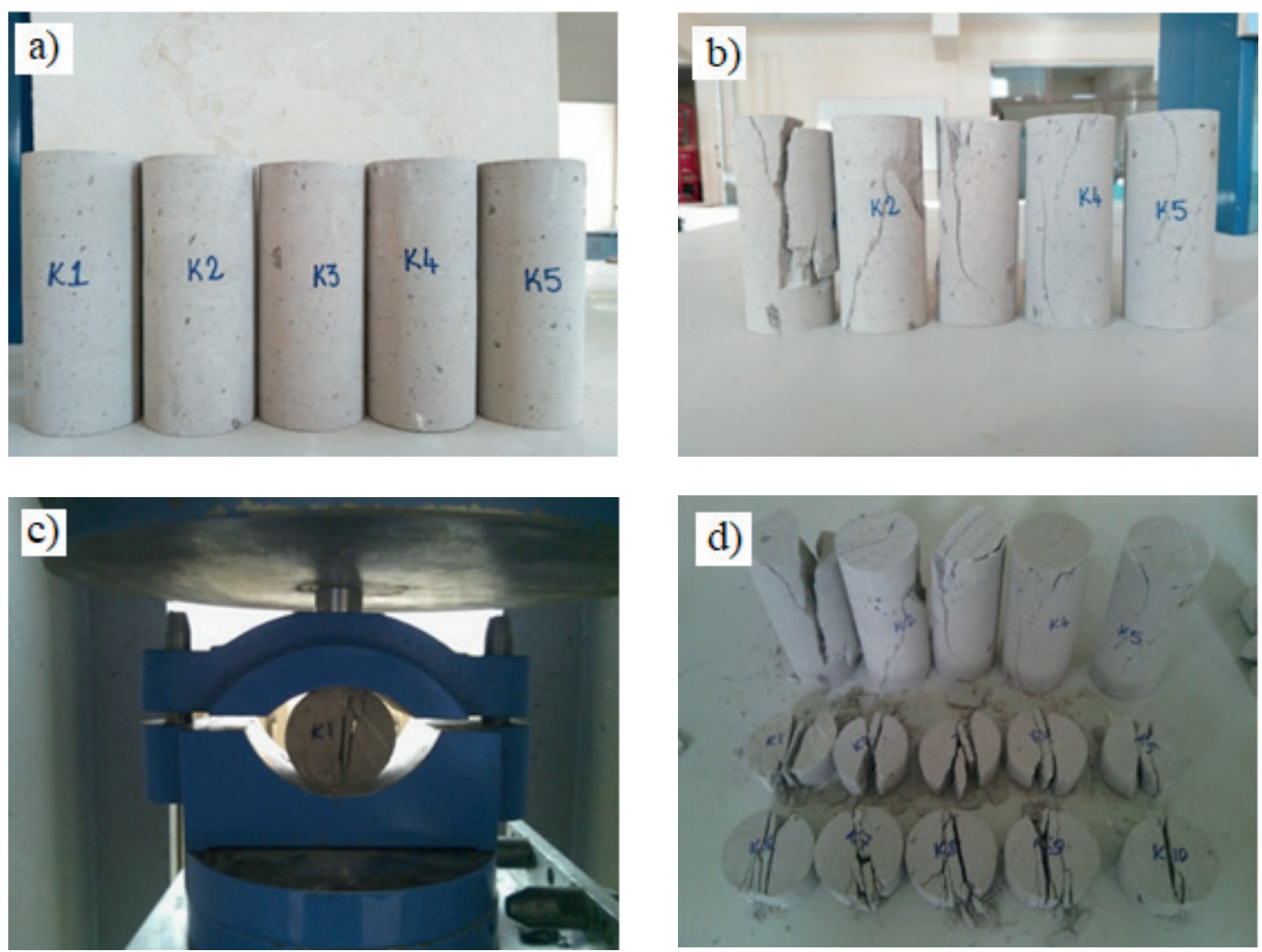

Fig. 6 Experimental tests a) Restoration stone, b) Crack formation following compressive load, c) Brazilian tensile test, d) Crack formation following the tensile test

In this equation, $\sigma$ is the compressive strength (MPa), $P_{k}$ is the ultimate load $(\mathrm{N})$ and $A$ is area of the sample $\left(\mathrm{mm}^{2}\right)$. Additionally, the tensile strength values of the test samples were obtained by using the Brazilian test (indirect test) (Fig. 6) [33]. This test is a well-known indirect method in engineering. The indirect tensile strength values of the specimens were calculated by using Eq. (4).

$\sigma=\frac{2 F}{\pi D t}$

Here, $\sigma, F, D$ and $t$ represent the splitting tensile strength $(\mathrm{MPa})$, failure load $(\mathrm{N})$, the diameter of the sample $(\mathrm{mm})$ and the thickness of the sample (mm). As a result of the experimental tests, the mechanical properties of the stone samples used in the Sütlü Minaret Mosque were obtained and presented in Table 3.

The rebound hammer test, one of the non-destructive testing (NDT) methods, was used to determine the existing mortar strengths on the cited historical structure. This test was applied to the mortar on the building walls in the horizontal direction and 20 different hardness readings were obtained according to ASTM D 5873-14. The hardness value of the mortar in the historical building was determined by taking the average of the 10 largest readings
Table 3 Mechanical properties of the stone samples

\begin{tabular}{lcccc}
\hline & $\begin{array}{c}\text { Compressive } \\
\text { Strength } \\
(\mathrm{MPa})\end{array}$ & $\begin{array}{c}\text { Tensile } \\
\text { Strength } \\
(\mathrm{MPa})\end{array}$ & $\begin{array}{c}\text { Elasticity } \\
\text { Modulus } \\
(\mathrm{GPa})\end{array}$ & $\begin{array}{c}\text { Specific } \\
\text { weight } \\
\left(\mathrm{t} / \mathrm{m}^{3}\right)\end{array}$ \\
\hline Original stone & 45.20 & 4.68 & 25.60 & 2.18 \\
Restoration stone & 13.12 & 1.82 & 12.94 & 1.95 \\
Mortar & 2.20 & - & 0.30 & - \\
\hline
\end{tabular}

from these values. The hardness of the mortar used in the walls of the Sütlü Minaret Mosque was obtained as 17. Then, the compressive strength value was calculated from the curve corresponding to the surface hardness according to the applied direction.

\subsection{Numerical modeling of masonry structures}

Masonry structures represent a large part of the existing constructions in the world. A great part of the historic architectural heritage consists of monumental masonry structures (buildings, towers, castles, churches, mosques, temples, etc.) [34]. Depending on the size of the structural system and the level of accuracy, three different modeling techniques which called detailed micro modeling, simplified micro modeling and macro modeling are generally preferred for numerical modelling of masonry structures [35]. 


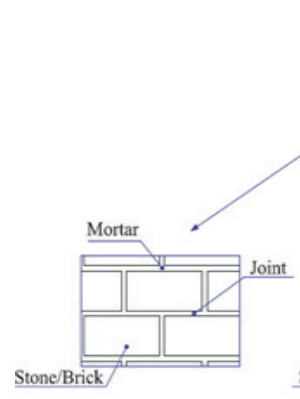

a)

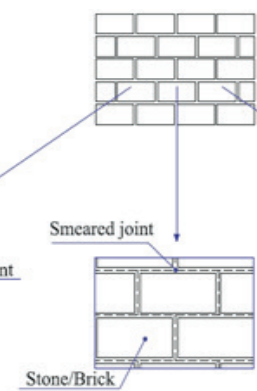

b)

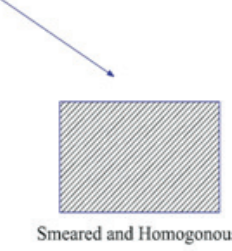

c)
Fig. 7 Modeling techniques for masonry structures, a) detailed micromodel, b) simplified micro-model, and c) macro model [36]

These modeling strategies are given in Fig. 7. Because of its low computational effort, macro-modelling technique is the most common technique for analysis of large-scale models and commonly used in the literature [37-40]. In the macro modelling strategy, stone or brick and mortar material is considered as a homogenized domain. In other words, masonry building elements and the mechanical characteristics of these materials are considered as a whole via the homogenization process and turned into a composite material with a single characteristic.

In previous studies, various equations were suggested for the determination of compressive strength of masonry walls. In this study, Eqs. (5)-(6) were considered [41-42]. The dimensions in the Eq. (6) can be seen in Fig. 4(b).

$$
\begin{aligned}
& f_{k}=e^{-0.317 \cdot L \cdot f} f b \\
& L=\sqrt[3]{l \times h \times t}
\end{aligned}
$$

In these equations, $f_{k}$ represents the compressive strength of the wall while $\mathrm{fb}$ represents the compressive strength of the masonry material. Additionally, $l, h$, and $t$ refer to width, height, and thickness of the wall, and $f$ refers to crack intensity factor, respectively. The elasticity modulus of the load-bearing wall, $E$, is determined by according to Turkish Building Earthquake Code (Eq. (7)) [43].

$E_{d u v}=750 f_{k}$

The characteristics of the materials used in the finite element model of the Sütlü Minaret Mosque were presented in Table 4. The material properties are defined as: $f_{c}$ is compressive strength and $f_{t}$ is tensile strength of material.

\section{Numerical analysis}

It is rather difficult to create numerical models of historical masonry structures, where various structural forms, such as minarets, churches, mosques, and bridges. The complexity created by the various architectural details of historical structures results in problems while modeling them. With the help of advanced computer technology and various finite element software, the modeling of structures with complex geometries has become possible [44]. In this study, three dimensional finite element model of the mosque was modelled with ANSYS [45] finite element software considering the actual dimensions of the mosque. For the 3D modelling of the mosque, SOLID 186 element was used. The finite element model of mosque is consisted of 12377 nodes and 6677 solid elements.

SOLID186 element is described by 20 nodes having three degrees of freedom per node and translations in the nodal $\mathrm{x}, \mathrm{y}$, and $\mathrm{z}$ directions. The geometry of the SOLID186 element was presented in Fig. 8.

The three-dimensional model of the mosque, which was created in the ANSYS software, was presented in Fig. 9. In the finite element model of the mosque, all degrees of freedom were accepted as fixed at foundation level.

\subsection{Modal analysis}

Dynamic characteristics of the mosque were evaluated with modal analysis. In the analysis, 5\% damping ratio was used $[1,4,5]$. The analytically identified first four mode shapes of the mosque were given in Fig. 10. Furthermore, the frequency data of the first 20 modes were presented in Table 5.

Table 4 Material properties of Sütlü Minaret Mosque used finite element model

\begin{tabular}{lccccc}
\hline $\begin{array}{l}\text { Type } \\
\text { of Material }\end{array}$ & $\begin{array}{c}f_{c} \\
(\mathrm{MPa})\end{array}$ & $\begin{array}{c}E \\
(\mathrm{MPa})\end{array}$ & $v$ & $\begin{array}{c}f_{t} \\
(\mathrm{MPa})\end{array}$ & $\begin{array}{c}\gamma \\
\left(\mathrm{kg} / \mathrm{m}^{3}\right)\end{array}$ \\
\hline Brick wall & 9.41 & 8000 & 0.20 & 1.27 & 1821 \\
Original wall & 28.36 & 21100 & 0.20 & 3.27 & 2180 \\
Restoration wall & 8.25 & 6175 & 0.20 & 1.15 & 1950 \\
\hline
\end{tabular}
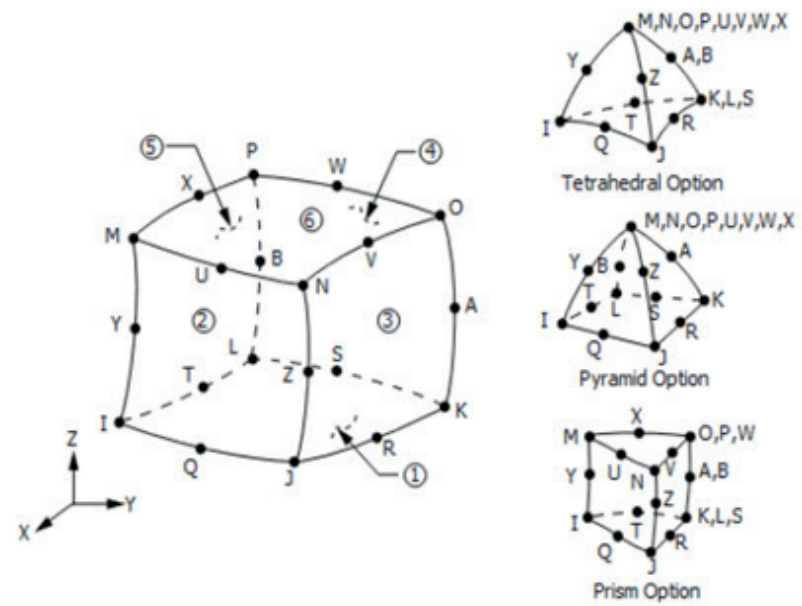

Fig. 8 The geometry of the SOLID186 element [45] 

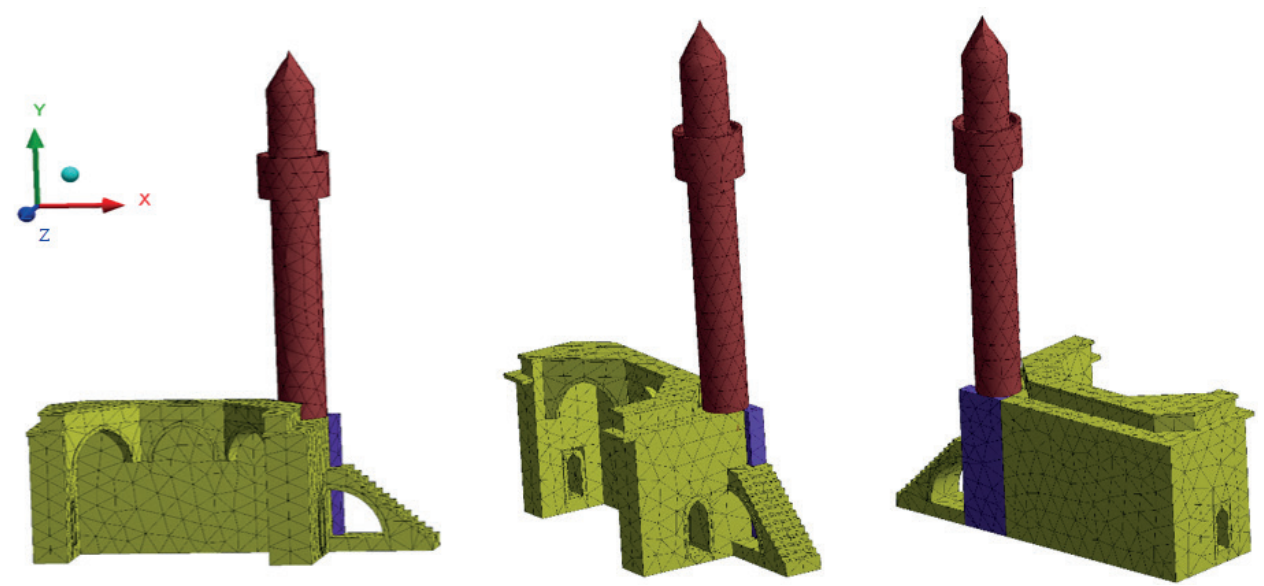

Fig. 9 Finite element model of the Sütlü Minaret Mosque for different angles

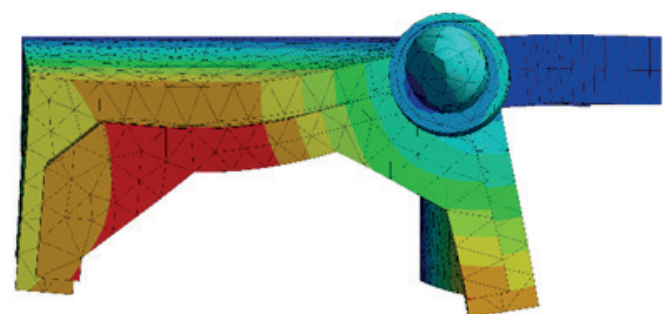

(a)

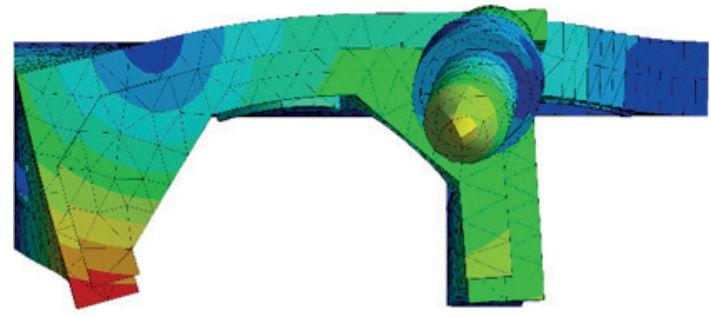

(c)

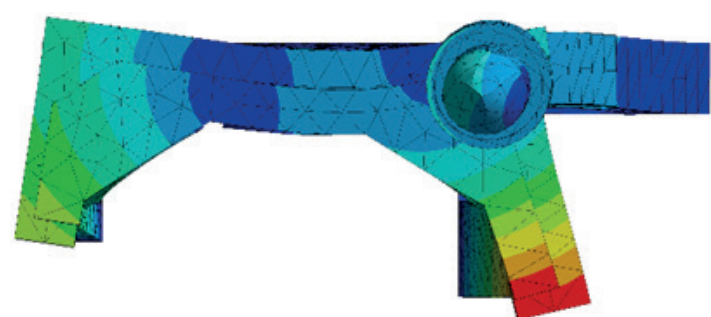

(b)

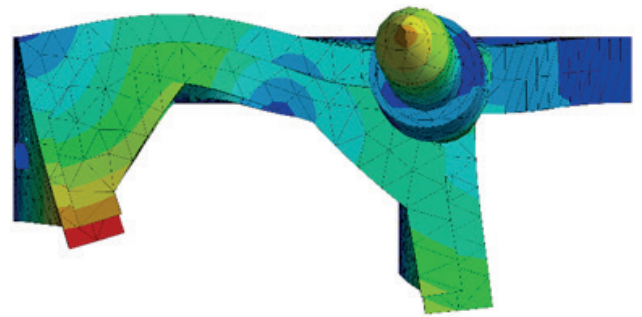

(d)

Fig. 10 First four mode shapes and frequencies of the mosque a) First mode $\left(f_{1}=1.8364 \mathrm{~Hz}\right)$, b) Second mode $\left(f_{2}=1.9716 \mathrm{~Hz}\right)$,

c) Third mode $\left(f_{3}=11.944 \mathrm{~Hz}\right)$, d) Fourth mode $\left(f_{4}=12.724 \mathrm{~Hz}\right)$

Table 5 First twenty frequencies

\begin{tabular}{|c|c|c|c|c|c|c|c|}
\hline$\frac{\pi}{\frac{0}{0}}$ & 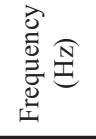 & $\frac{\stackrel{0}{0}}{\sum}$ & 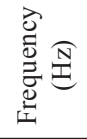 & $\frac{\frac{0}{0}}{\sum}$ & 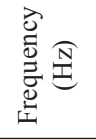 & $\begin{array}{l}\frac{0}{0} \\
\sum\end{array}$ & 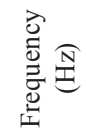 \\
\hline 1 & 1.8364 & 6 & 17.291 & 11 & 31.298 & 16 & 55.917 \\
\hline 2 & 1.9719 & 7 & 21.577 & 12 & 33.484 & 17 & 56.252 \\
\hline 3 & 11.944 & 8 & 22.7 & 13 & 39.438 & 18 & 58.942 \\
\hline 4 & 12.724 & 9 & 24.116 & 14 & 47.059 & 19 & 60.022 \\
\hline 5 & 14.274 & 10 & 27.124 & 15 & 53.864 & 20 & 61.937 \\
\hline
\end{tabular}

Also, two analytical formulas were used in this paper. Accordingly, the formulas in question processed the fundamental frequency numerically. The considered formulations are referred to general masonry buildings and not specifically to the historical masonry mosques. ASCE 07-16 presents a general expression for calculating a masonry structure's fundamental frequency (Eq. (8)) [46].
$f(H)=\frac{1}{0.0488 H^{3 / 4}}(H$ in meters $)$,

where $f$ is the natural frequency, $\mathrm{H}$ is the structural height of the roof above from the base, not including any parapet or penthouse. The following equation, which is essentially similar to ASCE 07-16, is recommended by the Italian Seismic Code (NTC-2008) for estimating the fundamental frequency of a masonry structure [47].

$f(H)=\frac{1}{0.05 H^{3 / 4}}(H$ in meters $)$

Eq. (9) is used for the buildings lower than 40 meters having a uniform mass distributed along the height. According to the Eqs. (8) and (9) the fundamental frequency was calculated as $1.8328 \mathrm{~Hz}$ and $1.7889 \mathrm{~Hz}$, respectively. In these equations, $\mathrm{H}$ was accepted as minaret height of the mosque. 


\subsection{Time history analysis}

Seismic performance of the mosque was evaluated by time-history analyses. For this purpose, six different earthquake acceleration records were selected. According to Interactive Earthquake Map of Turkey [20], these selected earthquake records were scaled according to elastic design spectrum of selected the location of the mosque. Seismomatch software was used for scaling the earthquake records [48]. Elastic design and acceleration spectrum graphs were obtained by considering the DD-2 level of earthquakes with a $10 \%$ probability of exceedance in 50 years and the location of the mosque from the Earthquake Hazard Map of Turkey. The acceleration records of the earthquakes to be used in the analyses were obtained from the website of the Pacific Earthquake Engineering Research Center (PEER) and Disaster and Emergency Management Agency (DEMA) [20, 49].

In the dynamic analyses, three components, NorthSouth, East-West, and Up-Down Direction, for each earthquake were taken into account, and each of the three components was applied to the mosque simultaneously. The properties of the selected ground motion records were given in Table 6. Furthermore, the earthquake acceleration-time graphs of the selected earthquakes used in the study were presented in Fig. 11.

As a result of the dynamic analyses, the absolute maximum displacement values were obtained on the peak points of the minaret in the $\mathrm{z}$ direction for all earthquakes.
The absolute maximum displacement values of the 1979 Imperial Valley, 1994 Northridge, 1999 Chi-Chi, 1999 Düzce, 2010 Darfield and 2020 Elazı̆g earthquakes on the $\mathrm{z}$ direction were $78.24 \mathrm{~mm}, 83.66 \mathrm{~mm}, 84.77 \mathrm{~mm}, 95.34 \mathrm{~mm}$, $92.41 \mathrm{~mm}$ and $62.50 \mathrm{~mm}$, respectively. The absolute peak displacement value for these earthquake records was obtained from the 1999 Düzce earthquake.

The contour diagrams of the displacement obtained from the 1999 Düzce earthquake were presented in Fig. 12. Also, the displacement-time graphs on $\mathrm{x}, \mathrm{y}$, and $\mathrm{z}$ directions were presented in Fig. 13 according to the peak point of the minaret which the highest displacement values were obtained.

The maximum principal compressive stress values obtained from the 1979 Imperial Valley, 1994 Northridge, 1999 Chi-Chi, 1999 Düzce and 2010 Darfield earthquakes were 2.2 $\mathrm{MPa}$, 1.80 $\mathrm{MPa}, 2.7 \mathrm{MPa}, 2.7 \mathrm{MPa}$, and 3 $\mathrm{MPa}$, respectively. Maximum stresses were observed to be

Table 6 Properties of selected earthquake records

\begin{tabular}{lccc}
\hline No & $\begin{array}{c}\text { Name of the } \\
\text { Earthquake }\end{array}$ & Recording Station & Magnitude $\left(M_{w}\right)$ \\
\hline 1 & $\begin{array}{c}\text { 1979 Imperial } \\
\text { Valley }\end{array}$ & $\begin{array}{c}\text { Aeropuerto } \\
\text { Mexical }\end{array}$ & 6.5 \\
2 & 2010 Darfield & HORC\& & 7.0 \\
3 & 1999 Chi-Chi & CHY\& Chy074 & 7.6 \\
4 & 1999 Düzce & Düzce & 7.1 \\
5 & 1994 Northridge & TPF000 & 6.7 \\
6 & 2020 Sivrice & 2308 & 6.8 \\
\hline
\end{tabular}
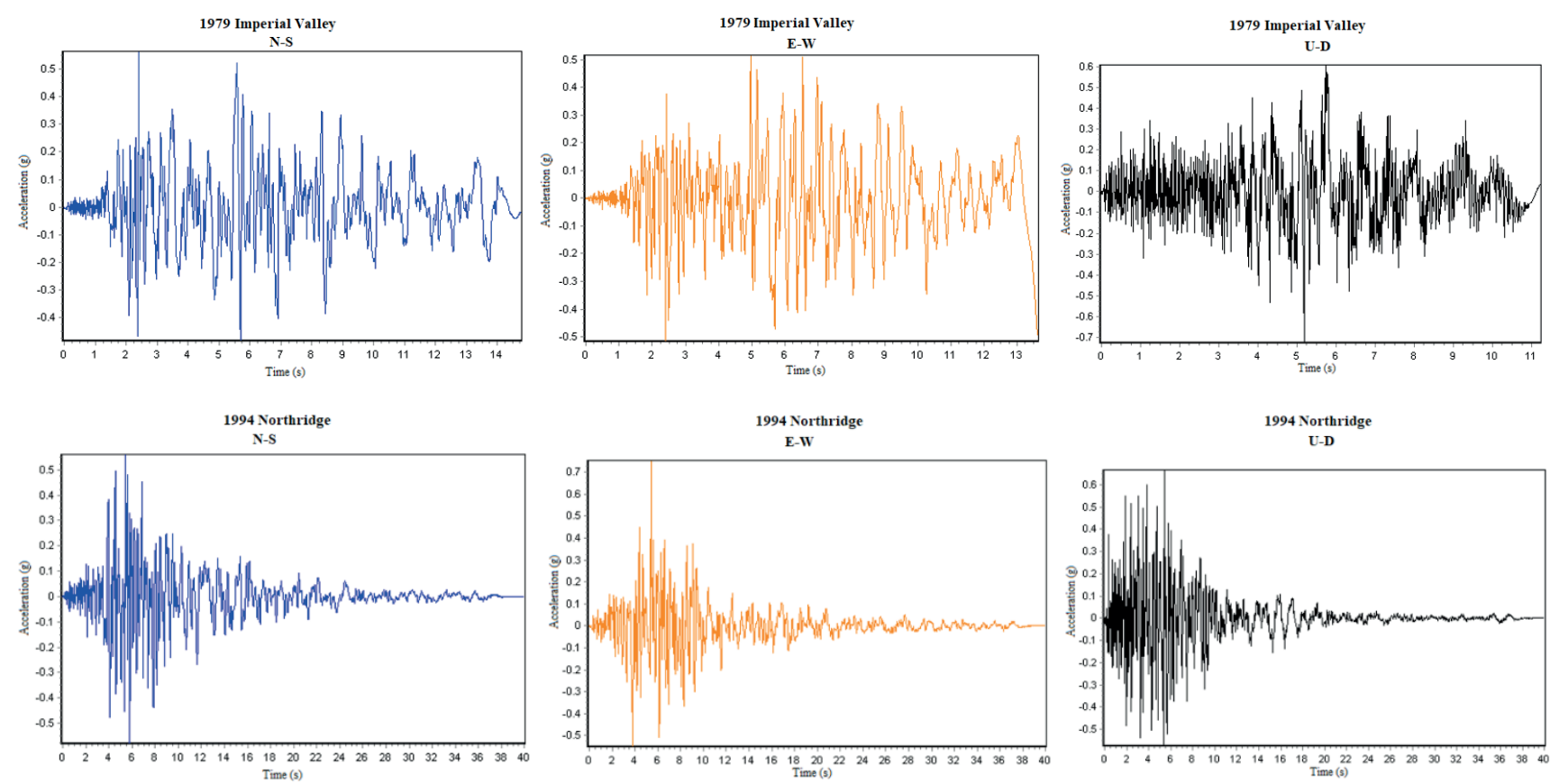

Fig. 11 Acceleration records of the earthquakes used in the analyses 

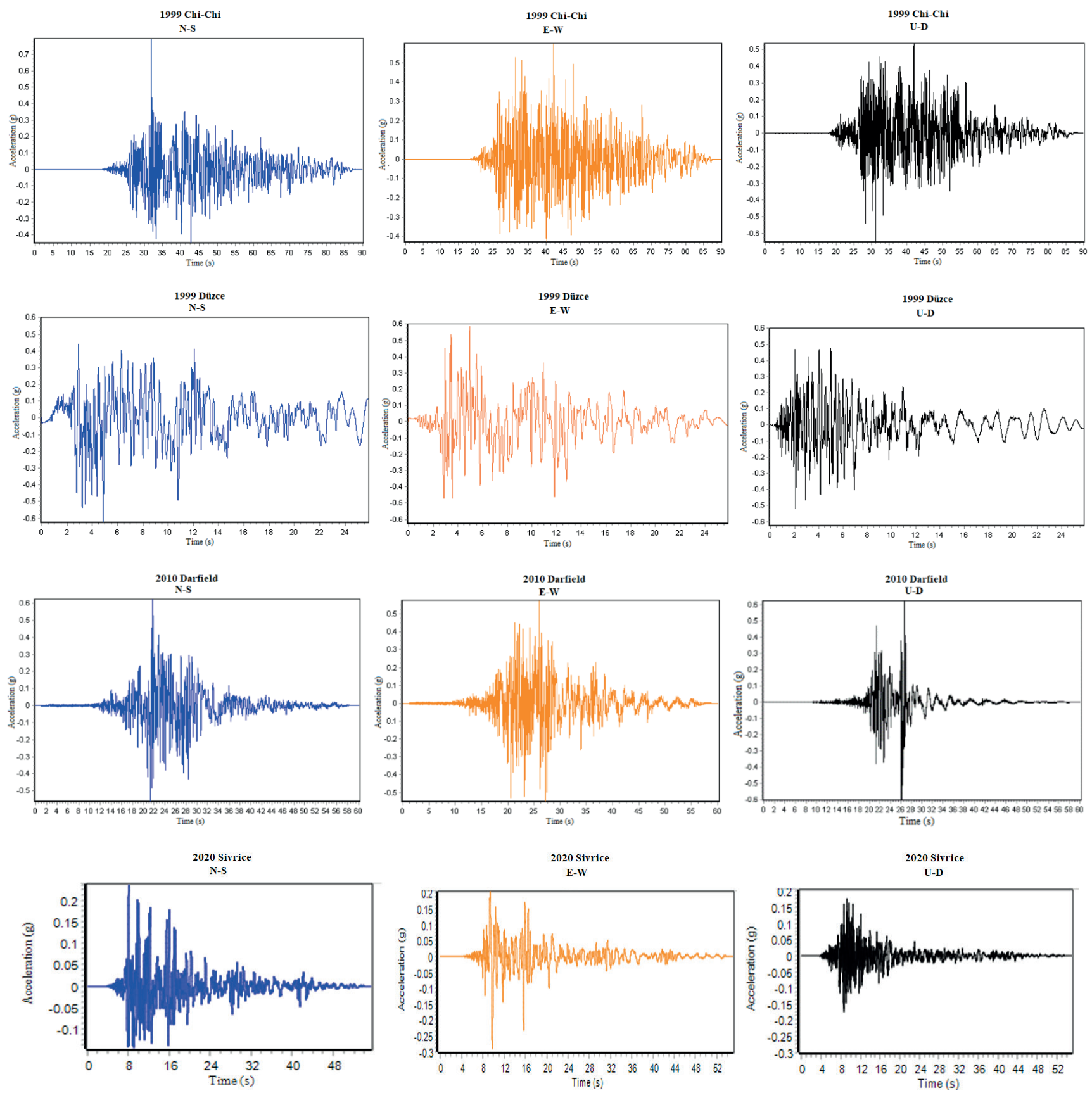

Fig 11 (continuation)

concentrated around the keystones of the arches, above the doors, the places where the walls were supported by the ground, and at the foot of the minaret. The maximum principal tensile stress values obtained from the 1979 Imperial Valley, 1994 Northridge, 1999 Chi-Chi, 1999 Düzce and 2010 Darfield earthquakes were 0.71 MPa, 1.87 MPa, 1.30 1.90 MPa, and 3.20 MPa, respectively. And these stresses were observed to be concentrated around the keystones of the arches, above the doors and windows, the places where the walls were supported by the ground, and at the foot of the minaret. Accordingly, it was observed that the highest principal compressive and tensile stress values were obtained in the 2010 Darfield earthquake. In Fig. 14, the contour diagrams of the maximum compressive and tensile stresses obtained from the 2010 Darfield earthquake were presented.

In the on-site analyses conducted after January 24, 2020, Elazı $\breve{g}$ earthquake $\left(M_{w}=6.8\right)$, it was observed that no damages occurred in the minaret of the mosque. Thus, the stresses that occurred in the minaret were not taken into account. A set of cracks were observed in the mosque after the following Elazı̆g earthquake. It was observed 


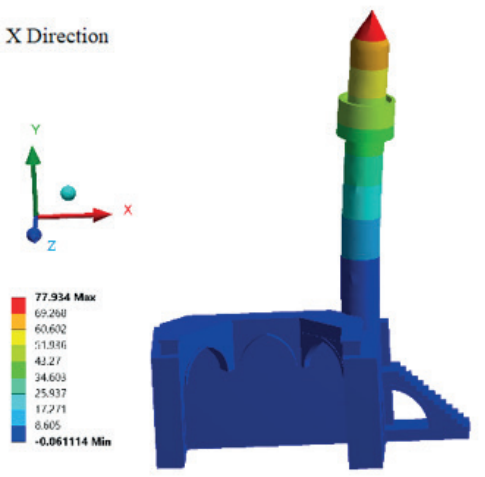

(a)

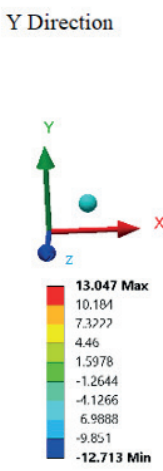

51

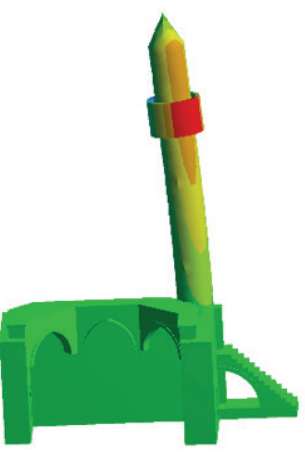

(b)

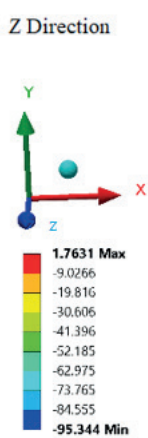

$-95.344 \mathrm{Mi}$

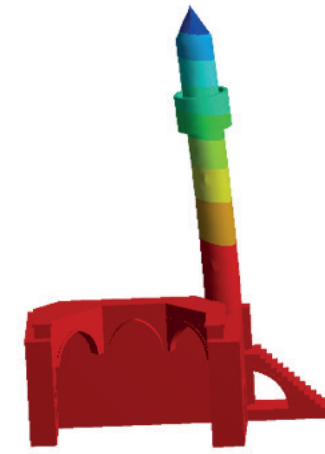

(c)

Fig. 12 Displacement contour diagrams of the mosque for the 1999 Düzce earthquake a) x direction, b) y direction, c) z direction
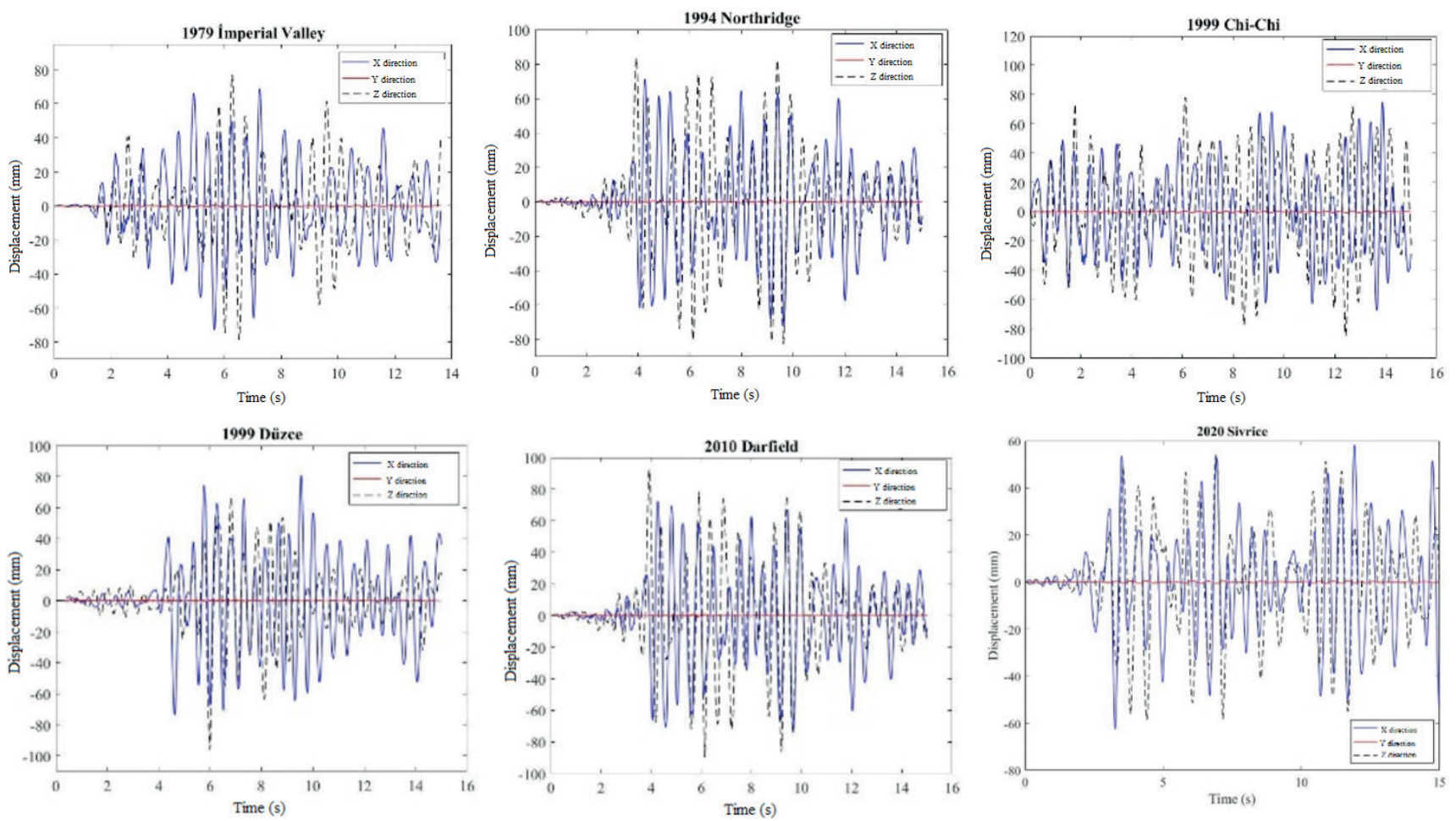

Fig. 13 Time history graphs of the peak point of the minaret for all acceleration records

that cracks were formed on the upper parts of the openings (doors), on the parts starting from the inner sections of the arches and continuing toward the upper sections of the mosque, and on the parts where the mosque was connected to the ground. As a result of the numerical analyses, it was obtained that the stress concentrations occurred in the parts of the mosque which were cracked by the earthquake. When the compressive and tensile strengths of the materials obtained in the study were compared to the stresses obtained from the numerical analyses, it was observed that the tensile stress that occurred in the three dimensional model exceeded the tensile strength of the material only in the restored section in the bottom part of the mosque. The observed cracked regions in the mosque and the numerical analysis results after the 24 January, 2020 Elazığ earthquake were given and compared in Fig. 15.

\section{Conclusions}

In this study, seismic behavior of the Historical Sütlü Minaret Mosque was investigated after January 24, 2020, Elazı ̆ earthquake by time-history analyses. Material properties of the mosque were defined by using non-destructive tests, uniaxial compressive tests and Brazilian tests (indirect test). In the time history analyses, six different strong ground motion records were used. These selected earthquake records were scaled according to the 


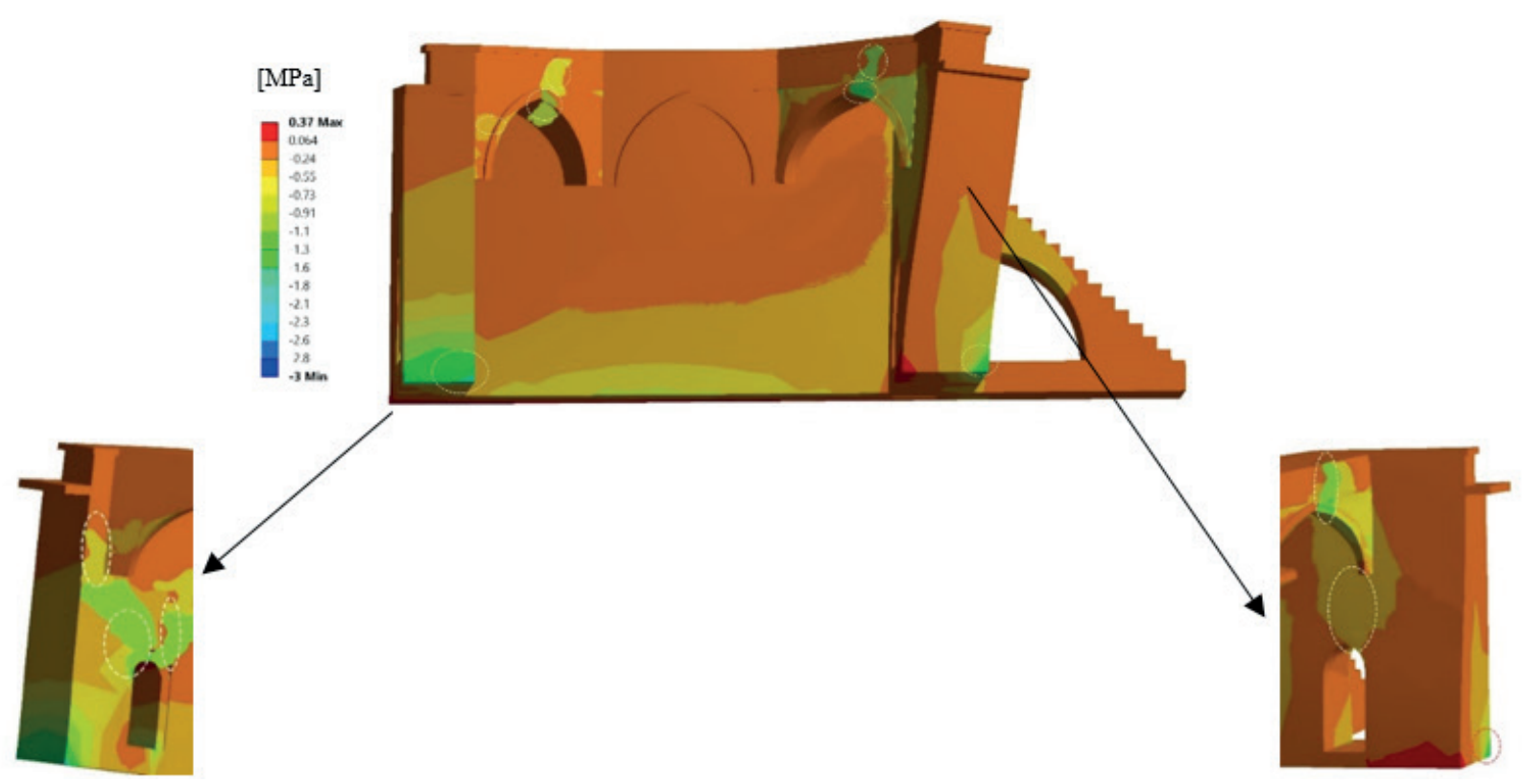

(a)

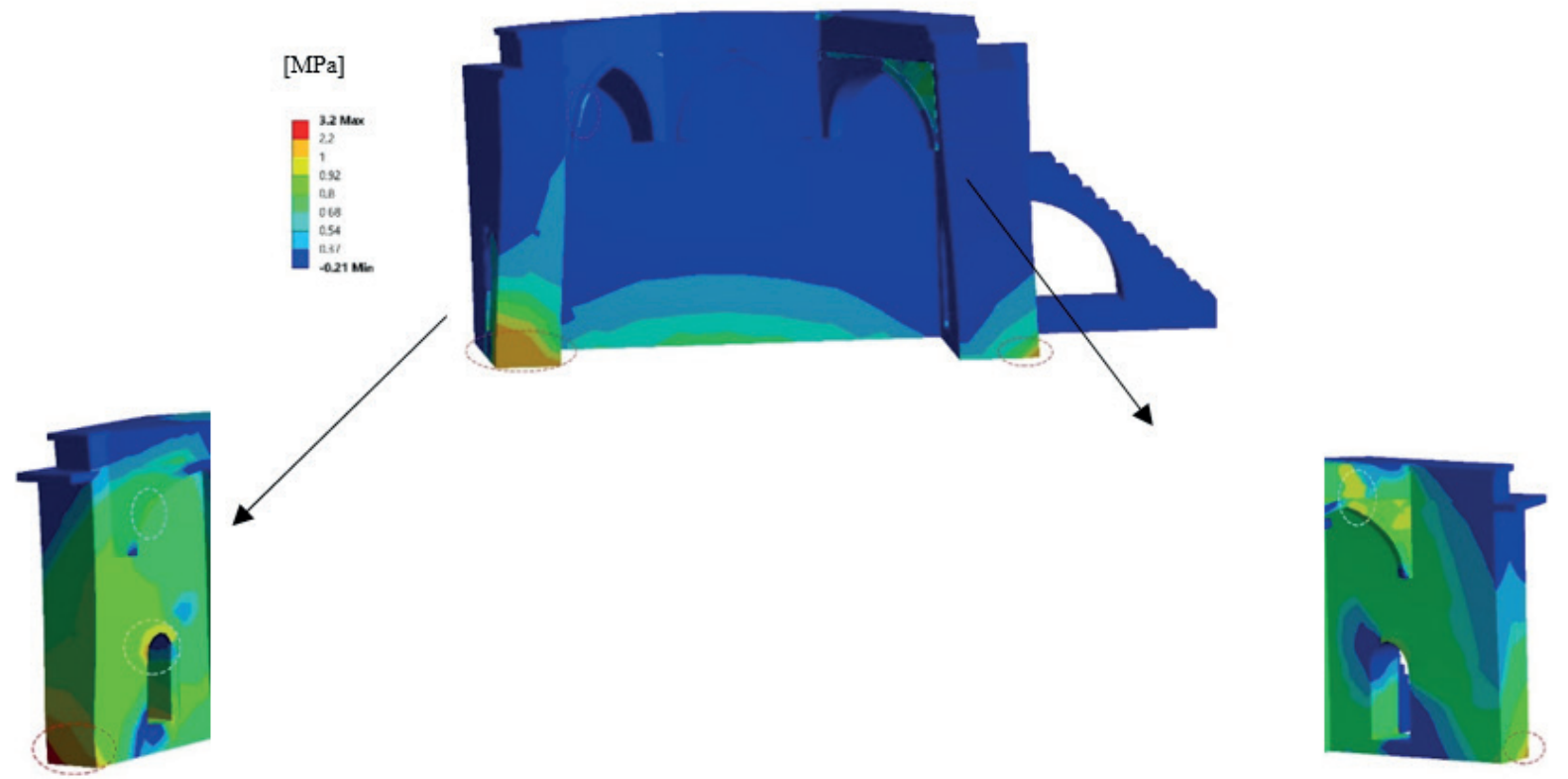

(b)

Fig. 14 Principal compressive and tensile stresses of the mosque for 2010 Darfield earthquake a) Principal compressive stress, b) Principal tensile stresses

location of the mosque. Maximum displacement and stress values which was obtained in the mosque were given. After the dynamic analyses, maximum compressive and tensile stresses were obtained in 2010 Darfield earthquake as $3 \mathrm{MPa}$ ad 3.2 $\mathrm{MPa}$, respectively. However, the obtained stress values were below the material strength. Maximum displacement value was obtained for 1999 Düzce earthquake as $95.34 \mathrm{~mm}$. Also, the time-history analyses were repeated for the 2020 Elazığ earthquake and obtained maximum and minimum stresses were compared the crack regions after the earthquake. The crack regions formed after the Elazı $\breve{g}$ earthquake are similar to the possible crack regions formed after the dynamic analysis. Carbon fiber textures which have been used in the strengthening of historical structures in recent years, can be used in the regions of the mosque that undergo high stress concentrations. Also, some stress intensity regions were obtained at the door openings. Since the mosque is not used today, reducing the door gaps will contribute to the integrity of the walls. In further studies, the mosque can be analyzed by nonlinear dynamic analysis and the crack propagation can be included in studies. 


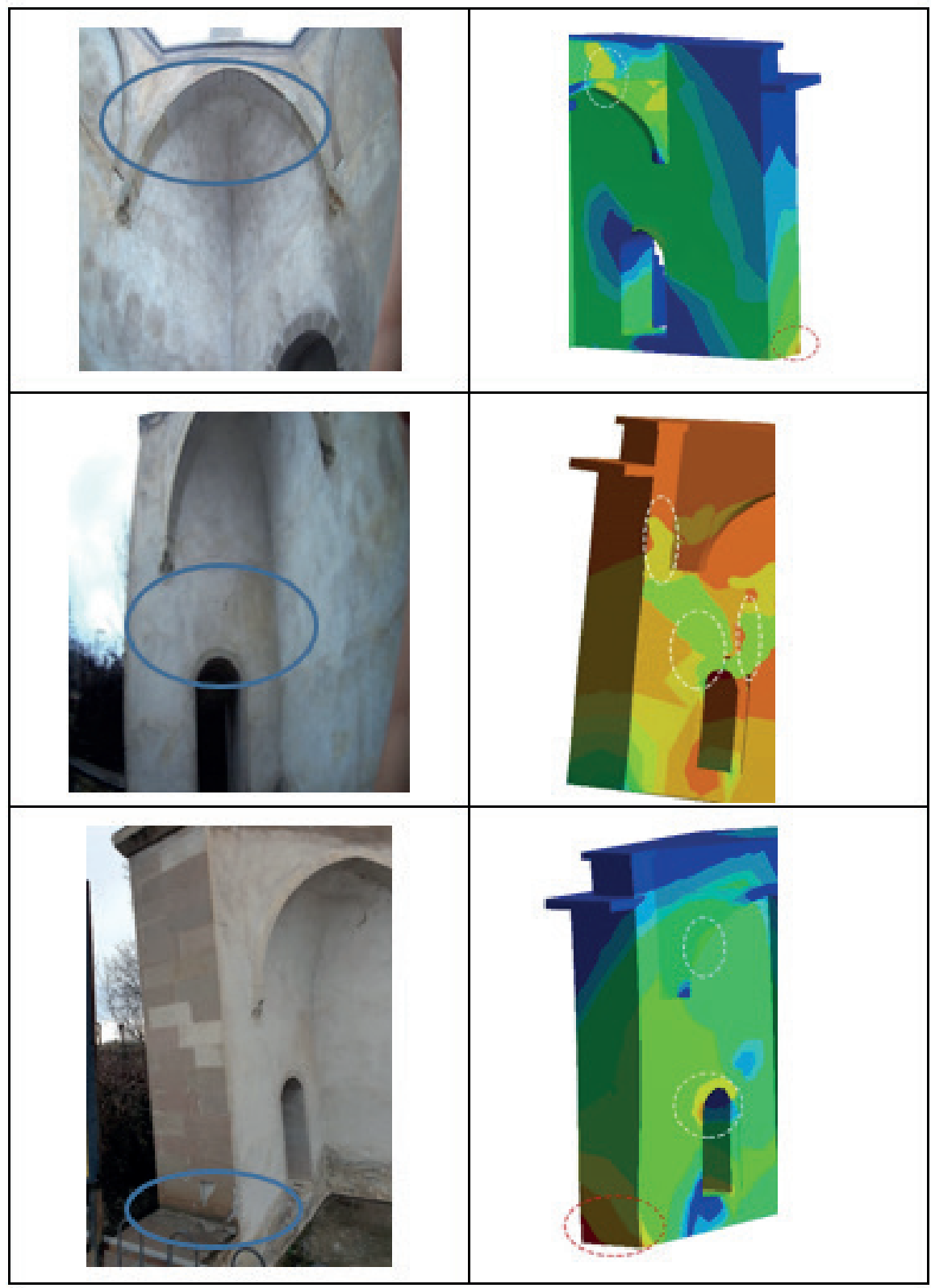

Fig. 15 The damages that occurred during the Elazı ̆g earthquake on January $24,2020\left(M_{w}=6.8\right)$

\section{References}

[1] Portioli, F., Mammana, O., Landolfo, R., Mazzolani, F. M., Krstevska, L., Tashkov, L., Gramatikov, K. "Seismic retrofitting of Mustafa Pasha Mosque in Skopje: finite element analysis", Journal of Earthquake Engineering, 15(4), pp. 620-639, 2011. https://doi.org/10.1080/13632469.2010.532580

[2] Seker, B. S., Cakir, F., Dogangun, A., Uysal, H. "Investigation of the structural performance of a masonry domed mosque by experimental tests and numerical analysis", Earthquakes and Structures, 6(4), pp. 335-350, 2014. https://doi.org/10.12989/eas.2014.6.4.335

[3] Koseoglu, G. C., Canbay, E. "Assessment and rehabilitation of the damaged historic Cenabı Ahmet Pasha Mosque", Engineering Failure Analysis, 57, pp. 389-398, 2015. https://doi.org/10.1016/j.engfailanal.2015.08.015
[4] Altunışık, A. C., Genç, A. F. "Earthquake response of heavily damaged historical masonry mosques after restoration", Natural Hazards and Earth System Sciences, 17(10), pp. 1811-1821, 2017. https://doi.org/10.5194/nhess-17-1811-2017

[5] Güllü, H., Karabekmez, M. "Effect of near-fault and far-fault earthquakes on a historical masonry mosque through 3D dynamic soil-structure interaction", Engineering Structures, 152, pp. 465492, 2017.

https://doi.org/10.1016/j.engstruct.2017.09.031

[6] Usta, P, Bozdağ, Ö. "Tarihi Başdurak Camisinin Deprem Analizi" (Earthquake analysis of historical Basdurak Mosque), Pamukkale University Journal of Engineering Sciences, 27(3), pp. 244-250, 2021. (in Turkish)

https://doi.org/10.5505/pajes.2020.31384 
[7] Bayraktar, A., Hökelekli, E., Türker, T., Çalik, I., Ashour, A., Mosallam, A. "Window opening effects on structural behavior of historical masonry Fatih Mosque", International Journal of Architectural Heritage, 13(4), pp. 585-599, 2018. https://doi.org/10.1080/15583058.2018.1447617

[8] Briccola, D., Bruggi, M. "Analysis of 3D linear elastic masonry-like structures through the API of a finite element software", Advances in Engineering Software, 133, pp. 60-75, 2019.

https://doi.org/10.1016/j.advengsoft.2019.04.009

[9] Özmen, A., Sayın, E. "Seismic Response of a Historical Masonry Bridge under Near and Far-fault Ground Motions", Periodica Polytechnica Civil Engineering, 65(3), pp. 946-958, 2021. https://doi.org/10.3311/PPci.17832

[10] Gönen, S., Soyöz, S. "Seismic analysis of a masonry arch bridge using multiple methodologies", Engineering Structures, 226, Article number: 111354, 2021.

https://doi.org/10.1016/j.engstruct.2020.111354

[11] Papa, G. S., Tateo, V., Parisi, M. A., Casolo, S. "Seismic response of a masonry church in Central Italy: the role of interventions on the roof", Bulletin of Earthquake Engineering, 19(2), pp. 11511179,2021 https://doi.org/10.1007/s10518-020-00995-w

[12] Zizi, M., Corlito, V., Lourenço, P. B., De Matteis, G. "Seismic vulnerability of masonry churches in Abruzzi region, Italy", Structures, 32, pp. 662-680, 2021. https://doi.org/10.1016/j.istruc.2021.03.013

[13] Yurdakul, M., Yılmaz, F., Artar, M., Can, Ö., Öner, E., Daloğlu, A. T. "Investigation of time-history response of a historical masonry minaret under seismic loads", Structures, 30, pp. 265-276, 2021. https://doi.org/10.1016/j.istruc.2021.01.008

[14] Kazaz, İ., Gülkan, P., Kazaz, E. "Numerical assessment of cracks on a freestanding masonry minaret", International Journal of Architectural Heritage, 15(4), pp. 526-547, 2021. https://doi.org/10.1080/15583058.2019.1629046

[15] Mangia, L., Ghiassi, B., Sayın, E., Onat, O., Lourenço, P. B. "Pushover Analysis of Historical Elti Hatun Mosque", presented at 12th International Congress on Advances in Civil Engineering, Istanbul, Turkey, Sept. 21-23, 2016. [online] Available at: http://hdl. handle.net/1822/43624

[16] McKenzie, D. P. "Active tectonics of the Mediterranean region", Geophysical Journal International, 30, pp. 109-185, 1972. https://doi.org/10.1111/j.1365-246X.1972.tb02351.x

[17] Duman, T. Y, Emre, Ö. "The East Anatolian Fault: geometry, segmentation and jog characteristics", Geological Society, London, Special Publications, 372(1), pp. 495-529, 2013. https://doi.org/10.1144/SP372.14

[18] Köküm, M., Inceöz, M. "Structural analysis of the northern part of the East Anatolian Fault System", Journal of Structural Geology, 114, pp. 55-63, 2018. https://doi.org/10.1016/j.jsg.2018.06.016

[19] Köküm, M., Özçelik, F. "An example study on re-evaluation of historical earthquakes: 1789 Palu (Elazığ) earthquake, Eastern Anatolia, Turkey", Bulletin of the Mineral Research and Exploration, (161), pp. $157-170,2020$ https://doi.org/10.19111/bulletinofmre.603929
[20] AFAD "Earthquake Department of the Disaster and Emergency Management Presidency", Ankara, Turkey, 2020. [online] Available at: https://en.afad.gov.tr/

[21] Köküm, M. "Landslides and lateral spreading triggered by the 24 January 2020 Sivrice earthquake (East Anatolian Fault)", Gümüşhane Üniversitesi Fen Bilimleri Dergisi, 11(3), pp. 751-760, 2021. https://doi.org/10.17714/gumusfenbil.877544

[22] Soysal, H, Sipahioğlu, S, Kolçak, D, Altinok, Y. "Historical Earthquake Catalogue of Turkey and Surrounding Area (2100 B.C. - 1900 A.D.)" TÜBİTAK, Ankara, Turkey, Rep. TBAG-341, 1981.

[23] ISRM "Suggested Methods for Determination of the Schmidt Rebound Hardness", International Journal of Rock Mechanics and Mining Science and Geomechanical Abstract, 15(3), pp. 101-102, 1978.

[24] ASTM "ASTM D 5873-14 Standard Test Method for Determination of Rock Hardness by Rebound Hammer Method", ASTM International, West Conshohocken, PA, USA, 2014. https://doi.org/10.1520/D5873-14

[25] Maras, M. M., Kose, M. M., Rizaoglu, T. "Microstructural Characterization and Mechanical Properties of Volcanic Tuff (Malatya, Turkey) Used as Building Stone for the Restoring Cultural Heritage", Periodica Polytechnica Civil Engineering, 65(1), pp. 309-319, 2021. https://doi.org/10.3311/PPci.16977

[26] Karaton, M., Aksoy, H. S. "Seismic damage assessment of an 891 years old historic masonry mosque", Periodica Polytechnica Civil Engineering, 62(1), pp. 126-135, 2018. https://doi.org/10.3311/PPci.10270

[27] ISRM "Suggested Methods for Determining Sound Velocity", International Journal of Rock Mechanics and Mining Science and Geomechanical Abstract, 15, pp. 53-58, 1978. https://doi.org/10.1016/0148-9062(78)91678-9

[28] ASTM "ASTM D2845-05 Standard Test Method for Laboratory Determination of Pulse Velocities and Ultrasonic Elastic Constants of Rock", ASTM International, West Conshohocken, PA, USA, 2005. https://doi.org/10.1520/D2845-05

[29] Martínez-Martínez, J., Benavente, D., García-del-Cura, M. A. "Spatial attenuation: the most sensitive ultrasonic parameter for detecting petrographic features and decay processes in carbonate rocks", Engineering Geology, 119(3-4), pp. 84-95, 2011. https://doi.org/10.1016/j.enggeo.2011.02.002

[30] Brotons, V., Tomás, R., Ivorra, S., Grediaga, A., Martínez-Martínez, J., Benavente, D., Gómez-Heras, M. "Improved correlation between the static and dynamic elastic modulus of different types of rocks", Materials and Structures, 49(8), pp. 3021-3037, 2016. https://doi.org/10.1617/s11527-015-0702-7

[31] Malhotra, V. M., Carino, N. J. "Handbook on nondestructive testing of concrete", CRC Press, Boca Raton, FL, USA, 2003. https://doi.org/10.1201/9781420040050

[32] ISRM "Suggested Methods for Determining the Uniaxial Compressive Strength and Deformability of Rock Materials", International Journal of Rock Mechanics and Mining Sciences, 15, pp. 99-103, 1979.

[33] Briševac, Z., Kujundžić, T., Čajić, S. "Current Cognition of Rock Tensile Strength Testing by Brazilian Test", The Mining-Geology Petroleum Engineering Bulletin, 30, pp. 101-114, 2015. (in Croatian) https://doi.org/10.17794/rgn.2015.2.2 
[34] D'Altri, A. M., Sarhosis, V., Milani, G., Rots, J., Cattari, S., Lagomarsino, S., Sacco, E., Tralli, A., Castellazzi, G., de Miranda, S. "Modeling strategies for the computational analysis of unreinforced masonry structures: review and classification", Archives of Computational Methods in Engineering, 27(4), pp. 1153-1185, 2020. https://doi.org/10.1007/s11831-019-09351-x

[35] Lourenço, P. B. "Computational strategies for masonry structures", PhD Thesis, Delft Technical University of Technology, 1996.

[36] Proske, D., Gelder, P. "Safety of historical arch bridges", Springer, Berlin, Heidelberg Germany, 2009. https://doi.org/10.1007/978-3-540-77618-5

[37] Hökelekli, E., Demir, A., Ercan, E., Nohutçu, H., Karabulut, A. "Seismic Assessment in a Historical Masonry Minaret by Linear and Non-linear Seismic Analyses", Periodica Polytechnica Civil Engineering, 64(2), pp. 438-448, 2020. https://doi.org/10.3311/PPci.15126

[38] Özmen, A., Sayın, E. "Seismic assessment of a historical masonry arch bridge", Journal of Structural Engineering \& Applied Mechanics, 1(2), pp. 95-104, 2018. https://doi.org/10.31462/jseam.2018.01095104

[39] Yazdani, M. "Three-dimensional Nonlinear Finite Element Analysis for Load-Carrying Capacity Prediction of a Railway Arch Bridge", International Journal of Civil Engineering, 19, pp. 823-836, 2021. https://oi.org/10.1007/s40999-021-00608-w

[40] Karalar, M., Yeşil, M. "Investigation on Seismic Behavior of Historical Tokatlı Bridge under Near-Fault Earthquakes", Advances in Civil Engineering, 2021, Article ID 5596760, 2021. https://doi.org/10.1155/2021/5596760

[41] Tsoutrelis, C. E, Exadaktylos, G. E. "Effect of rock discontinuities on certain rock strength and fracture energy parameters under uniaxial compression", Geotechnical \& Geological Engineering, 11(2), pp. 81-105, 1993. https://doi.org/10.1007/BF00423337
[42] Kazaz I., Kocaman İ. "Seismic load capacity evaluation of stone masonry mosques", Journal of the Faculty of Engineering and Architecture of Gazi University, 33(2), pp. 543-558, 2018. https://doi.org/10.17341/gazimmfd.416365

[43] Turkish Building Earthquake Code, (TBEC) "Ministry of Public Works and Settlement", 2018. [online] Available at: http://www. bayindirlik.gov.tr

[44] Aşıkoğlu, A., Avşar, Ö., Lourenço, P. B., Silva, L. C. "Effectiveness of seismic retrofitting of a historical masonry structure: Kütahya Kurşunlu Mosque, Turkey", Bulletin of Earthquake Engineering, 17(6), pp. 3365-3395, 2019 https://doi.org/10.1007/s10518-019-00603-6

[45] ANSYS. "Finite Element Software, Swanson Analysis System", 2015. [online] Available at: https://www.ansys.com/

[46] ASCE "ASCE 07-16 Minimum Design Loads and Associated Criteria for Buildings and Other Structures", American Society of Civil Engineers, Reston, VI, USA, 2017.

[47] Ministry of Infrastructure and Transport "Aggiornamento delle «Norme Tecniche per le Costruzioni»" (Update of the «Technical Standards for Construction»), Gazette Ufficiale Della Republica Italiana, 42(8), (Sup. of Law 27-02-2004, no. 46) 2018. (in Italian)

[48] Seismosoft Ltd. "Seismomatch (2018)" [computer program] Available at: https://seismosoft.com/product/seismomatch/[Accessed: 18 April 2021]

[49] The Pacific Earthquake Engineering Research Center "PEER NGAWest2", [database] Available at: https://ngawest2.berkeley.edu/ [Accessed: 18 April 2021] 